\title{
Uji Keandalan Model Harmonisasi Hubungan Industrial pada Gudang Tembakau di Kabupaten Jember
}

\author{
Henik Prayuginingsih, Teguh Hari Santosa dan Muhammad Iman \\ Fakultas Pertanian, Universitas Muhammadiyah Jember \\ Jl. Karimata 49 Jember 68121 \\ Email: hprayuginingsih@yahoo.co.id
}

\begin{abstract}
ABSTRAK
Penelitian ini bertujuan untuk menguji kehandalan model harmonisasi hubungan industrial pada gudang tembakau di Kabupaten Jember. Dengan menggunakan teknik analisis skoring, tabulasi silang, dan FGD, hasil-hasil penelitian menunjukkan bahwa model harmonisasi hubungan industrial perlu disempurnakan dalam bentuk: (1) perbaikan atribut perlindungan, pengadaan lembaga keuangan pengganti koperasi, pemberian asuransi pengganti Jamsostek, peningkatan pengetahuan buruh akan keberadaan SPSI, perbaikan hubungan buruh-SPSI dan buruh-perusahaan; (2) melibatkan ATI mendampingi pemerintah dalam mengawasi dan memfasilitasi hubungan industrial pada gudang tembakau; (3) peran mandor sebagai mediator buruh-perusahaan digantikan kepala gudang yang mempunyai kedudukan lebih strategis di SPSI. Hasil simlasi penerapan model hanya mampu meningkatkan skor perlindungan dan kepuasan kerja namun tidak pada hubungan industrial. Hanya gudang PT Perkebunan Nusantara yang mempunyai hubungan industrial harmonis sebelum dan sesudah penerapan model.
\end{abstract}

Kata Kunci: Uji Keandalan, Model Harmonisasi, Hubungan Industrial

\begin{abstract}
The purpose of this paper is to study the reliability of a harmonization model of industrial relations at the tobacco warehouse in Kabupaten Jember. By employing a scoring technique, cross-tabulation, and $F G D$, it is found that the model still needs revision in the form of: (1) improving some protection attributes, the establishment of cooperation to replace the function of cooperation, replaced Jamsostek with insurance programs, increasing labor knowledge about SPSI, improving relationship between labor-SPSI and labor-company; (2) involving the ITA to accompany government to control and facilitate industrial relations at tobacco warehouse; (3) replacing the role of supervisors as a mediator laborcompany by head of warehouse which has strategic position in SPSI. The simulated model just could increase the score of protection and statisfiction, but not on industrial relations in harmony. The harmonious industrial relations are only found at PT Perkebunan Nusantara before and after the application of the model.
\end{abstract}

Keywords: Reliability Test, Harmonization Model, Industrial Relations

\section{PENDAHULUAN}

Menurut penelitian Azizah (2007) buruh pada gudang tembakau di daerah Jember dan Bondowoso yang $97-99 \%$ diantaranya wanita, sering mengalami kekerasan psikis dalam bentuk pelecehan seksual, ketakutan dipecat setiap saat, dan pengawasan yang ketat selama bekerja. Disamping itu, juga banyak hakhaknya yang tidak terpenuhi, antara lain: jam kerja yang terlalu panjang, jam istirahat yang singkat, kesempatan menjalankan ibadah yang terbatas, upah di bawah Upah Minimum Regional (UMR), kondisi kerja yang tidak nyaman serta fasilitas keselamatan dan kesehatan kerja yang minim (Prayuginingsih, 2007). Hak buruh pada berbagai aspek merupakan perlindungan yang seharusnya diberikan perusahaan, dan persepsi buruh terhadap perlindungan perusahaan tercermin pada kepuasan kerja. Interaksi antara perlindungan dan kepuasan kerja menggambarkan hubungan industrial (Simamora, 2001). 
Penelitian Prayuginingsih et al. (2010) pada enam gudang tembakau menunjukkan bahwa lima diantaranya mempunyai hubungan industrial yang belum harmonis. Ketidakharmonisan terlihat dari kategori tingkat perlindungan sedang dan direspon buruh dengan kepuasan kerja pada kategori sedang pula. Satu-satunya gudang yang mempunyai hubungan industrial harmonis adalah PT Perkebunan Nusantara (PTPN X), yang mempunyai tingkat perlindungan dan kepuasan kerja tinggi. Terdapat 12 atribut perlindungan yang mempunyai skor rendah, yaitu pengetahuan buruh akan keberadaan SPSI, hubungan buruh-Serikat Pekerja Seluruh Indonesia (SPSI), hubungan buruh-perusahaan, keberadaan koperasi, upah rutin, perjanjian kerja, pemutusan hubungan kerja (PHK), pemberian pesangon, Jaminan Sosial Tenaga Kerja (JAMSOSTEK) dan perbaikan kondisi kerja.
Model harmonisasi hubungan industrial telah dibuat dan model tersebut perlu diuji keandalannya serta direvisi dan disempurnakan agar buruh dapat memperoleh perlindungan dan kepuasan kerja yang lebih tinggi.

\section{METODE PENELITIAN}

Uji keandalan model dimulai dengan simulasi penerapan model, melalui simulasi dapat digali respon buruh wanita terhadap kemungkinan terjadinya perubahan atribut-atribut perlindungan. Berdasarkan respon tersebut maka dapat diketahui apakah model sudah dapat diterapkan, masih perlu direvisi atau perlu disempurnakan untuk mencapai hubungan industrial yang harmonis (Umar, 1998). Adapun langkah-langkah uji keandalan, revisi dan penyempurnaan model yang merupakan alur penelitian tercantum pada Gambar 1.

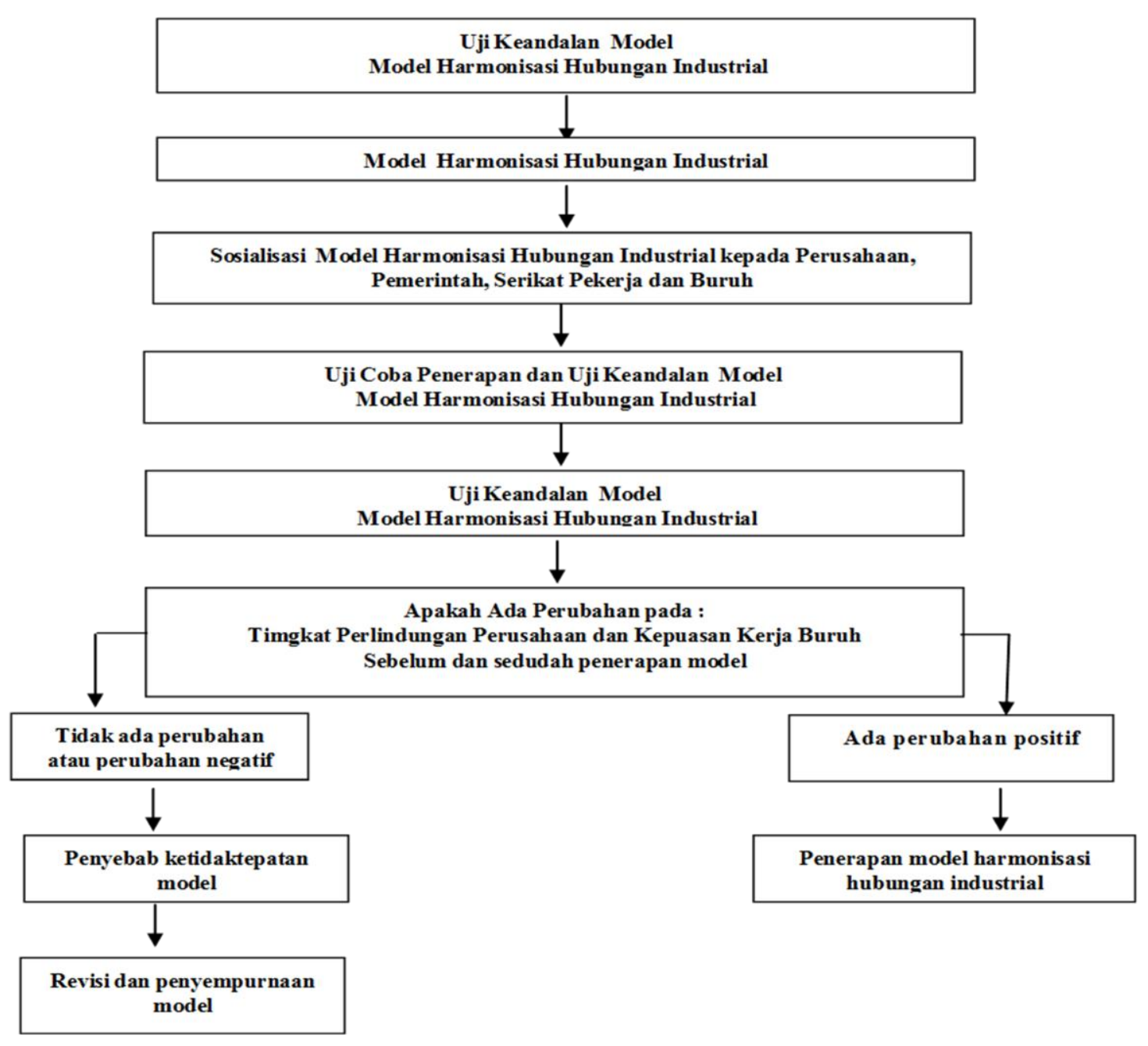

Gambar 1. Diagram Aliran Pelaksanaan Penelitian Model Harmonisasi Hubungan Industrial 
Penelitian ini menggunakan pendekatan deskriptif analitis untuk memperoleh data tentang existing condition hubungan industrial gudang tembakau baik sebelum maupun setelah penerapan model harmonisasi hubungan industrial.

Uji ketepatan, evaluasi dan penyempurnaan model dilakukan melalui focus group discussion (FGD) dengan pendekatan simulasi partisipatif, yang melibatkan pengusaha, buruh, mandor, serikat pekerja dan pemerintah.

Penelitian dilaksanakan pada bulan MaretSeptember 2011 dengan populasi penelitian sebanyak 97 unit usaha gudang tembakau. Sampel terdiri atas satu gudang yang dikelola Badan Usaha Milik Negara (BUMN) dan lima gudang swasta yang memiliki Serikat Pekerja. Sampel buruh dan mandor adalah buruh dan mandor yang sama dengan penelitian pada saat penyusunan model yang diambil secara disproportionate random sampling dengan komposisi sebagaimana tercantum pada Tabel 1 .

\section{Tabel 1. Penentuan Sampel Penelitian}

\begin{tabular}{lr}
\hline \multicolumn{1}{c}{ Uraian } & Jumlah \\
\hline Populasi gudang tembakau & 97 \\
Sampel gudang tembakau & 6 \\
Responden & \\
- Pemerintah/Disnaker Kabupaten Jember & 1 \\
- Pengelola gudang tembakau & 6 \\
- Buruh @ 30 orang per gudang & 180 \\
- Serikat Pekerja & 6 \\
Total jumlah responden & 193 \\
\hline
\end{tabular}

Data penelitian meliputi data primer dan data sekunder. Data primer terdiri atas: (a) atribut untuk menentukan tingkat perlindungan terhadap buruh; (b) atribut untuk menentukan tingkat kepuasan kerja buruh; (c) peran dan fungsi serikat pekerja, kepala gudang, pemerintah dan Asosiasi Tembakau Indonesia (ATI). Data sekunder diperoleh dari Dinas Tenaga Kerja Kabupaten Jember. Teknik pengumpulan data adalah survey dan indepth interview serta focus group discussion (FGD) pada saat menilai keandalan, mengevaluasi dan menyempurnakan model.

Pengolahan data untuk mengetahui kondisi faktual hubungan industrial sebelum dan sesudah uji keandalan model menggunakan teknik tabulasi silang dan skor. Kondisi hubungan industrial ditentukan oleh interaksi antara tingkat perlindungan perusahaan dan tingkat kepuasan kerja buruh.

Tingkat perlindungan perusahaan (protection) dan tingkat kepuasan kerja buruh (statisfiction) ditentukan berdasar nilai rata-rata skor. Berdasarkan Hadi (1991), skor masing-masing atribut tingkat perlindungan dan kepuasan kerja ditentukan sebagai berikut:

a. Skor $=5$, jika atribut perlindungan atau kepuasan kerja sangat tinggi

b. Skor $=4$, jika atribut perlindungan atau kepuasan kerja dinilai tinggi c. Skor $=3$, jika atribut perlindungan atau kepuasan kerja dinilai sedang

d. Skor $=2$, jika atribut perlindungan atau kepuasan kerja dinilai rendah

e. Skor $=1$, jika atribut perlindungan atau kepuasan kerja sangat rendah

Kategori tingkat perlindungan dan tingkat kepuasan buruh adalah:

a. Sangat tinggi : jika rata-rata skor $\geq 4,50$

b. Tinggi : jika rata-rata skor 3,50-4,49

c. Sedang : jika rata-rata skor $2,50-3,49$

d. Rendah : jika rata-rata skor $1,50-2,49$

e. Sangat rendah: jika rata-rata skor $<1,49$

Kriteria Pengambilan Keputusan:

a. Kondisi hubungan industrial harmonis, apabila tingkat perlindungan perusahaan dan tingkat kepuasan kerja buruh yang tinggi.

b. Kondisi hubungan industrial belum harmonis, apabila tingkat perlindungan perusahaan sedang dan kepuasan kerja buruh juga sedang atau bahkan tinggi

c. Kondisi hubungan industrial tidak harmonis, apabila tingkat perlindungan perusahaan dan tingkat kepuasan kerja buruh rendah.

Untuk menguji keandalan model harmoniasi hubungani industrial dilakukan simulasi penerapan model dengan langkah-langkah sebagai berikut:

1. Sosialisasi dan klarifikasi kondisi hubungan industrial sebelum penerapan model

2. Simulasi penerapan model pada masing-masing gudang tembakau

3. Penyusunan model alternatif

4. Evaluasi hasil simulasi penerapan model alternatif

5. Revisi dan penyempurnaan model

\section{HASIL DAN PEMBAHASAN}

\section{Kondisi Hubungan Industrial pada Gudang Tembakau di Kabupaten Jember Sebelum Penerapan Model}

Berdasarkan hasil penelitian terdahulu (Prayuginingsih et al., 2010) diketahui bahwa hanya satu gudang yang mempunyai hubungan industrial harmonis, yaitu Gudang PTPN X. Hubungan industrial yang harmonis ditunjukkan dengan tingkat perlindungan yang tinggi dan direspon dengan tingkat kepuasan kerja buruh yang tinggi pula.

Hubungan industrial pada Gudang Pandusata, GMIT dan Tarutama belum harmonis, karena baik perlindungan maupun kepuasan kerja berada pada kategori sedang. Kondisi yang menarik terjadi pada gudang Tempurejo, dimana hubungan industrial belum 
harmonis karena tingkat perlindungan kategori sedang, namun direspon dengan kepuasan yang tinggi. Satusatunya gudang yang tidak harmonis adalah MDR, karena tingkat perlindungan yang rendah.

\section{Tingkat Perlindungan Perusahaan kepada Buruh Wanita}

Hasil penelitian pada tahun pertama menunjukkan bahwa dari enam gudang lokasi penelitian hanya satu yang mempunyai tingkat perlindungan dengan kriteria tinggi, yaitu gudang milik PTPN X, dengan skor rata-rata 3,57. Lima gudang lainnya mempunyai kisaran rata-rata skor tingkat perlindungan 2,57-2,98 sehingga termasuk dalam kategori sedang (Tabel 2). Beberapa atribut yang mempunyai skor perlindungan rendah adalah: (a) upah rutin; (b) tidak adanya pesangon jika terkena PHK; (c) tidak adanya JAMSOSTEK bagi buruh; (d) tidak adanya koperasi untuk meningkatkan kesejahteraan buruh; (e) minimnya fasilitas sanitasi; (f) terjadinya hubungan kerja tanpa perjanjian; (g) pemberlakuan PHK; (h) rendahnya pengetahuan buruh pada SPSI; (i) hubungan buruh dan
SPSI; dan (j) hubungan buruh dan perusahaan (Tabel $3)$.

\section{Tingkat Kepuasan Kerja Buruh Wanita}

Kepuasan kerja adalah persepsi pekerja terhadap lingkungan kerjanya sebagai hasil interaksi manusia dengan lingkungan kerja. Menurut As'ad (2003). Pengukuran kepuasan kerja selain dapat didasarkan atas perasaan seorang pekerja terhadap aspek-aspek pekerjaannya, juga dapat didasarkan atas seberapa banyak kebutuhan pekerja dapat terpenuhi.

Berdasarkan kebutuhan pekerja yang dapat terpenuhi, maka atribut yang paling sering termasuk dalam kategori kepuasan kerja rendah adalah: (a) tidak adanya insentif lain selain upah rutin dan upah lembur; (b) tunjangan hari raya (THR) yang dinilai terlalu rendah; dan (c) kekurangtahuan buruh akan keberadaan SPSI, sebagai lembaga yang memperjuangkan kepentingan mereka (Tabel 4). Berdasarkan kondisi faktual, maka dibuat model harmonisasi hubungan industrial sebagaimana disajikan pada Gambar 2.

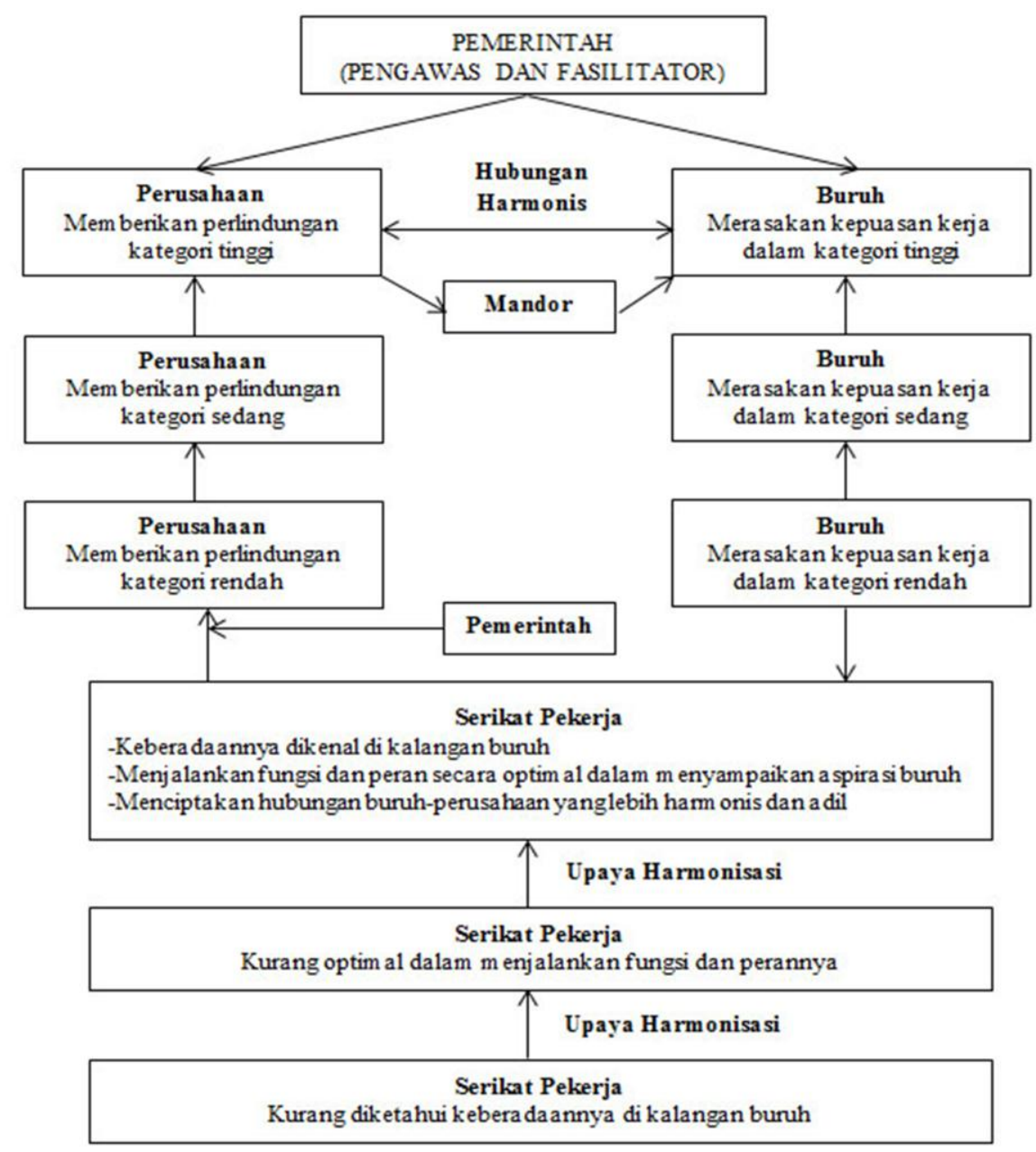

Gambar 2. Model Harmonisasi Hubungan Industrial Pada Gudang Tembakau di Kabupaten Jember 
Tabel 2. Hasil Simulasi Perbaikan Atribut Perlindungan

\begin{tabular}{|c|c|c|}
\hline Atribut Perlindungan & $\begin{array}{c}\text { Kendala yang dihadapi untuk upaya } \\
\text { peningkatan/perbaikan }\end{array}$ & Upaya perbaikan/peningkatan \\
\hline $\begin{array}{l}\text { Pengetahuan buruh akan keberadaan } \\
\text { SPSI }\end{array}$ & $\begin{array}{l}\text { - Ketidakpedulian buruh } \\
\text { - Keterbatasan daya fikir buruh } \\
\text { - Keterbatasan waktu buruh }\end{array}$ & Dapat dilaksanakan \\
\hline Hubungan buruh dengan SPSI & - Relatif tidak ada & Dapat dilaksanakan \\
\hline Hubungan buruh dengan perusahaan- & - Niat baik perusahaan & Dapat dilaksanakan \\
\hline Kondisi lantai dan sanitasi & - Kemampuan finansial perusahaan & Belum dapat dilaksanakan \\
\hline Perjanjian hubungan kerja & $\begin{array}{l}\text { - Status buruh sebagai karyawan tidak } \\
\text { tetap } \\
\text { - Perekrutan tenaga tidak langsung, tetapi } \\
\text { melalui mandor }\end{array}$ & $\begin{array}{l}\text { Belum dapat dilaksanakan } \\
\text { i }\end{array}$ \\
\hline Pemberlakuan PHK & $\begin{array}{l}\text { - Produksi tergantung permintaan pasar } \\
\text { - Permintaan pasar dipengaruhi isu } \\
\text { global anti merokok }\end{array}$ & $\begin{array}{l}\text { Buruh diupayakan bekerja pada } \\
\text { bagian lain } \\
\text { Pekerjaan dibagi secara merata pada } \\
\text { tiap anggota team kerja }\end{array}$ \\
\hline $\begin{array}{l}\text { Pemberian pesangon jika terjadi } \\
\text { PHK }\end{array}$ & $\begin{array}{l}\text { - Status buruh sebagai karyawan tidak } \\
\text { tetap } \\
\text { - Pekerjaan fluktuatif dan tidak kontinyu } \\
\text { sepanjang tahun } \\
\text { - Perekrutan tenaga kerja dilakukan } \\
\text { mandor berdasar perkiraan produksi } \\
\text { yang diberikan perusahaan } \\
\text { - Kondisi finansial perusahaan }\end{array}$ & Belum dapat dilaksanakan \\
\hline Pemberian JAMSOSTEK & $\begin{array}{l}\text { - Status buruh sebagai karyawan tidak } \\
\text { tetap } \\
\text { - Pekerjaan gudang tidak kontinyu } \\
\text { - Jangka waktu JAMSOSTEK panjang }\end{array}$ & $\begin{array}{l}\text { Diganti dengan program asuransi } \\
\text { yang durasi waktunya lebih singkat }\end{array}$ \\
\hline Pengupahan & - Kemampuan finansial perusahaan & $\begin{array}{l}\text { Dapat dilaksanakan sesuai } \\
\text { kemampuan perusahan }\end{array}$ \\
\hline $\begin{array}{l}\text { Pengadaan koperasi atau lembaga } \\
\text { keuangan lainnya }\end{array}$ & Kemampuan finansial perusahan & $\begin{array}{l}\text { Belum dapat dilaksanakan oleh } \\
\text { semua gudang }\end{array}$ \\
\hline
\end{tabular}

\section{Uji Coba Ketepatan dan Keandalan Model}

Uji coba ketepatan dan keandalan model dilakukan dengan menerapkan model harmonisasi hubungan industrial melalui simulasi perbaikan atribut perlindungan yang mempunyai skor rendah dengan hasil tercantum pada Tabel 2.

\section{Pengetahuan Buruh akan Keberadaan SPSI}

Pengetahuan buruh akan keberadaan dan manfaat SPSI menimbulkan rasa aman dan percaya diri bahwa ada yang memperjuangkan kepentingan mereka. Rasa aman dan percaya diri dapat meningkatkan kepuasan kerja, yang diharapkan merupakan umpan balik bagi perusahaan agar buruh lebih meningkat kinerjanya.

Tugas mensosialisasikan SPSI dapat dilakukan oleh atasan buruh yang sehari-hari bergaul di gudang. Para atasan biasanya mengenal karakter masing- masing buruh, sehingga pengenalan SPSI dapat disesuaikan dengan kondisi mereka, sehingga kendala ketidak pedulian, keterbatasan daya pikir dan keterbatasan waktu buruh dapat diatasi.

\section{Hubungan Buruh dengan SPSI}

Hubungan antara buruh dan perusahaan yang belum baik selama ini disebabkan oleh pengetahuan buruh yang rendah akan keberadaan SPSI. Apabila perusahaan sudah dapat mensosialisasikan SPSI kepada buruh akan terjalin hubungan baik antara buruh dan SPSI. Hubungan yang baik antara buruh dan SPSI akan menghapus prasangka buruk pada SPSI dan perusahaan, sehingga mereka akan memahami dan bahkan mendukung program SPSI dan perusahaan.

Kendala yang mungkin dihadapi relatif tidak ada, hanya tergantung pada kemampuan para atasan 
untuk memberikan pemahaman pada buruh akan manfaat keberadaan SPSI bagi buruh dan perusahaan.

\section{Hubungan Buruh Perusahaan}

Hubungan yang diharapkan terjadi antara perusahan dan buruh pada hubungan industrial adalah kemitraan. Perusahaan yang menganggap buruh sebagai mitra akan memperlakukan karyawan atau buruh sebagai aset atau kekayaan, bukan sekedar faktor produksi yang hanya dituntut untuk memberikan produktivitas tinggi.

Seperti aset lainnya, buruh perlu dipertahankan keberadaannya, karena berpengaruh terhadap kelangsungan hidup perusahaan. Upaya yang dapat dilakukan untuk mempertahankan buruh adalah dengan memperhatikan kebutuhan dan kepentingan mereka, baik fisik maupun psikis. Jika perusahaan belum mampu memenuhi semua kebutuhan fisik, setidaknya dapat memenuhi kebutuhan psikis seperti: menghargai dan memperlakukan secara manusiawi atau menempatkan mereka pada kelompok kerja yang tidak mempunyai konflik pribadi. Buruh yang terpenuhi kebutuhannya, akan puas dengan pekerjaannya, sehingga memberikan umpan balik berupa kesadaran untuk bekerja sesuai dengan harapan perusahaan.

Satu-satunya kendala yang mungkin timbul dari upaya menumbuhkan hubungan kemitraan ini adalah niat baik perusahaan. Mengingat manfaat yang akan diperoleh perusahaan dari hubungan kemitraan, maka disarankan pada perusahan untuk menumbuhkan sikap tersebut.

\section{Perbaikan Kondisi Lantai, Ventilasi, dan Sanitasi}

Saran perbaikan sarana ventilasi dan sanitasi dinyatakan berat untuk dilaksanakan, karena kendala finansial perusahaan yang belum memungkinkan. Perbaikan lantai, ventilasi dan sanitasi membutuhkan dana yang besar, sementara pada saat yang bersamaan perusahaan juga dituntut untuk melakukan penyesuaian upah buruh. Pada sisi lain, kondisi pasar tembakau tidak sebagus sebelum tahun 80-an, saat belum terdengar kampanye anti rokok dan tembakau.

\section{Perbaikan Perjanjian Hubungan Kerja}

Perbaikan perjanjian hubungan kerja juga tidak dapat dilaksanakan. Kendala yang dihadapi, karena para buruh merupakan tenaga tidak tetap yang hanya bekerja jika ada pekerjaan. Oleh karena itu, perusahan merasa tidak ada kewajiban untuk melakukan perjanjian kerja, karena buruh wanita juga bebas untuk menolak tawaran pekerjaan gudang.

Kendala lainnya adalah perekrutan tenaga kerja tidak dilakukan secara langsung dengan perusahaan melainkan oleh mandor yang merupakan kepala pekerja. Mandorlah yang memilih pekerja sebagai tim kerjanya, sehingga perjanjian hanya terjadi antara buruh dan mandor.

\section{Pemberlakuan PHK}

Kebutuhan tenaga ditentukan oleh perkiraan permintaan pasar oleh fihak manajemen. Berdasarkan jumlah permintaan ditentukan jumlah produksi dan buruh yang dibutuhkan. Selanjutnya fihak manajemen menghubungi kepala pekerja yang akan merekrut pekerja. Apabila permintaan pasar sedang menurun berarti hanya sedikit buruh yang diperlukan sehingga PHK tidak dapat dihindari.

Pekerjaan pada gudang tembakau bersifat terputus-putus, yaitu antara bulan Maret-Juni dan September-Desember. PHK jarang dilakukan di tengah musim bekerja, jika tidak ada pelanggaran yang sangat serius.

Apabila penurunan produksi tidak terlalu drastis disertai dengan keinginan untuk menjalin kemitraan dengan buruh, perusahaan akan berusaha tidak melakukan PHK terhadap buruh wanita yang sudah biasa bekerja selama bertahun-tahun pada perusahaan dengan jalan:

- Menyalurkan buruh yang tidak bekerja di gudang ke pekerjaan lain, seperti di kebun misalnya

- Membagi pekerjaan secara merata pada setiap pekerja, meskipun masing-masing memperoleh sedikit kesempatan bekerja.

\section{Pemberian Pesangon Jika terjadi PHK}

Pemberian pesangon tidak dapat diberikan karena empat kendala, yaitu:

- Status buruh sebagai karyawan tidak tetap dan tidak mempunyai perjanjian kerja

- Pekerjaan fluktuatif dan tidak kontinu sepanjang tahun, sehingga kemungkinan ada saja yang terkena PHK. Jika setiap buruh yang terkena PHK memperoleh pesangon maka perusahaan akan terbebani dengan biaya pesangon yang sangat besar.

- Perekrutan tenaga kerja dilakukan mandor berdasar perkiraan produksi yang diberikan perusahaan, sehingga jika ada PHK dilakukan oleh mandor bukan oleh perusahaan.

- Kondisi finansial perusahaan yang terbatas. 


\section{JAMSOSTEK Bagi Buruh}

JAMSOSTEK mewajibkan pesertanya membayar iuran dengan jumlah tertentu secara rutin dalam jangka waktu lama selama masa bekerja. JAMSOSTEK tidak dapat diberikan pada buruh wanita digudang tembakau karena beberapa kendala, yaitu:

- dengan status pegawai tidak tetap, buruh dapat sewaktu-waktu berhenti dan tidak ada yang bertanggung jawab terhadap JAMSOSTEK atas namanya.

- pekerjaan gudang yang tidak kontinu akan menyulitkan pekerja membayar iuran rutin dalam jangka waktu lama

Berdasarkan hal tersebut, maka untuk memberikan jaminan keselamatan kerja pada buruh, gudang GMIT dan Tempurejo mengganti program JAMSOSTEK yang berjangka waktu panjang dengan program asuransi kecelakaan yang mempunyai jangka waktu lebih pendek dan disesuaikan dengan kondisi buruh. Salah satu bentuk penyesuaian adalah dengan memberikan talangan pembayaran premi terlebih dahulu dan dibayar dengan cara diangsur setiap kali buruh menerima upah. Diharapkan penyertaan buruh pada program asuransi akan menambah rasa aman dan tenang buruh dalam bekerja.

\section{Pengupahan}

Berdasarkan Peraturan Gubernur Jawa Timur Nomor 93 tahun 2010, Upah Minimum Kabupaten (UMK) Jember ditetapkan Rp875.000/bulan atau Rp35.000/hari. Selain itu, ada juga ketentuan UMK khusus sebesar $80 \%$ dari UMK normal bagi perusahaan padat karya, seperti gudang tembakau, yang menanggung biaya tenaga kerja minimal 25\% dari biaya total produksi. Upah buruh gudang tembakau minimal sebesar Rp 664.000/bulan atau Rp 26.500/ hari. Hasil penelitian menunjukan bahwa upah/hari buruh wanita pada seluruh lokasi penelitian masih dibawah UMR. PTPN adalah gudang yang memberikan upah harian tersbesar, yaitu Rp 24.000/hari sementara rata-rata upah gudang lainnya adalah $\mathrm{Rp}$ 23.500/hari.

Upaya peningkatan upah sudah dilakukan yaitu sebesar Rp24.500/hari, meskipun kenaikan ini masih di bawah UMK Jember, namun niat baik perusahaan harus dihargai. Besarnya kenaikan ini sudah dirundingkan oleh pihak perusahaan dengan SPSI dan diawasi oleh Disnaker Kabupaten Jember dan ATI.
Pengadaan Koperasi atau Lembaga Keuangan Lainnya

Koperasi atau lembaga keuangan bentuk lain sudah ada pada gudang MDR, Tarutama dan PTPN $\mathrm{X}$ dengan skor tiga, artinya ada unit simpan pinjam yang dapat dimanfaatkan untuk memenuhi kebutuhan mendadak buruh. Respon buruh pada tiga gudang berbeda: (a) pada gudang PTPN X buruh puas dengan kategori tinggi; (b) pada gudang Tarutama buruh puas dengan kategori sedang; dan (c) pada gudang MDR buruh puas dengan kategori rendah. Berdasarkan pada kondisi ini, maka perbaikan bukan ditujukan untuk pengadaan koperasi melainkan pada peningkatan pelayanan pada buruh agar dapat merasakan manfaat koperasi.

Tiga gudang lainnya belum ada koperasi, namun GMIT mempunyai lembaga informal yang melayani kebutuhan mendadak buruh. Keberadaan lembaga informal terbukti mampu melayani kebutuhan buruh, sehingga meski hanya berbentuk lembaga informal namun mampu memberikan kepuasan dengan kategori sedang. Sementara itu buruh Gudang Pandusata dan Tempurejo belum memperoleh kepuasan dari atribut ini, karena ketiadaan koperasi dan lembaga keuangan lain, baik formal maupun informal.

Mengacu pada kondisi faktual gudang GMIT maka pembentukan lembaga keuangan informal yang dapat memenuhi kebutuhan mendadak buruh dan memberikan kepuasan dapat menjadi model untuk mengupayakan hubungan industrial yang lebih harmonis. Satu-satunya kendala penerapan model ini adalah kemampuan finansial perusahaan.

\section{Penyusunan Model Alternatif}

Model alternatif menyarankan tujuh atribut yang perlu diprioritaskan perusahaan untuk diperbaiki atau ditingkatkan, yaitu: (a) peningkatan pengetahuan buruh akan keberadaan SPSI; (b) perbaikan hubungan buruh dengan SPSI; (c) perbaikan hubungan buruh dengan perusahaan; (d) menghindari terjadinya PHK; (e) penyertaan buruh pada program asuransi; (f) peningkatan upah buruh; dan (f) pengadaan koperasi atau lembaga keuangan, baik formal maupun informal. Tiga atribut perlindungan lainnya, yaitu: (a) perjanjian kerja; (b) pemberian pesangon; serta (c) perbaikan kondisi lantai, ventilasi dan sanitasi akan diperbaiki atau ditingkatkan pada waktu dan kesempatan yang lain, apabila kondisi finansial perusahaan sudah memungkinkan. 
Tabel 3. Perlindungan Buruh Gudang Tembakau di Kabupaten Jember Sebelum dan Setelah Penerapan Model Alternatif

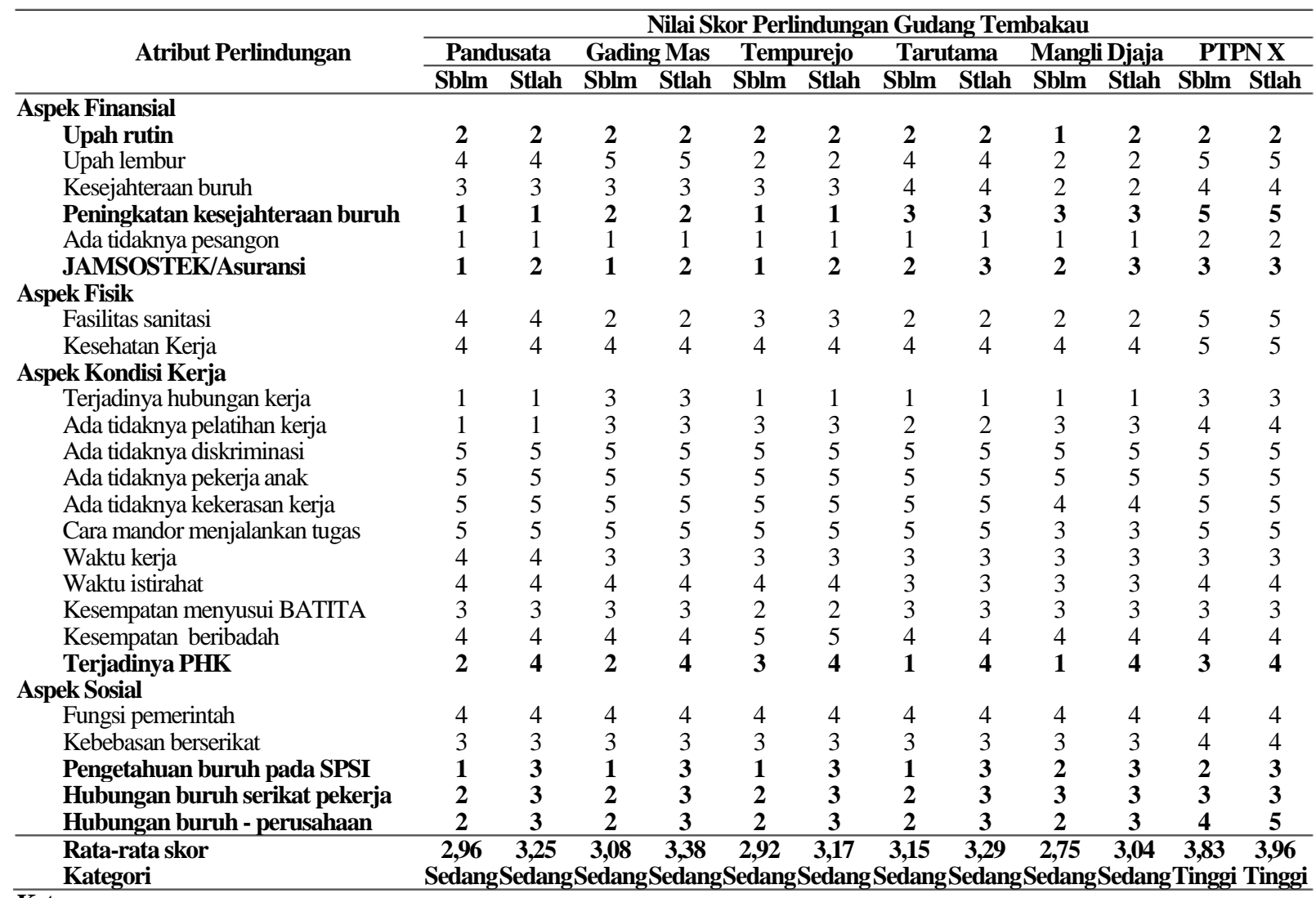

Keterangan:

Kategori sangat tinggi: skor $\geq 4,5$; Kategori tinggi: skor 3,5 - 4,4; Kategori sedang: skor 2,5 - 3,4; Kategori rendah: skor 1,5 - 2,4; Kategori sangat rendah: skor $<1,5$

Tabel 4. Rata-rata Tertimbang Kepuasan Buruh Gudang Tembakau di Kabupaten Jember Sebelum dan Setelah Penerapan Model Alternatif

\begin{tabular}{|c|c|c|c|c|c|c|c|c|c|c|c|c|}
\hline \multirow{3}{*}{ Aspek Pekerjaan } & \multicolumn{12}{|c|}{ Rata-rata Tertimbang Skor Kepuasan } \\
\hline & \multicolumn{2}{|c|}{ Pandusata } & \multicolumn{2}{|c|}{ Gading Mas } & \multicolumn{2}{|c|}{ Tempurejo } & \multicolumn{2}{|c|}{ Tarutama } & \multicolumn{2}{|c|}{ Mangli Djaya } & \multicolumn{2}{|c|}{ PTPN X } \\
\hline & Sblm & Stlh & Sblm & Stlh & Sblm & Stlh & Sblm & Stlh & Sblm & Stlh & Sblm & Stlh \\
\hline \multicolumn{13}{|l|}{ Aspek Finansial } \\
\hline -Upah rutin & 3,93 & 4,30 & 4,33 & 4,70 & 4,00 & 4,00 & 3,00 & 3,00 & 2,10 & 2,10 & 3,97 & 3,97 \\
\hline -Upah lembur & 3,20 & 3,20 & 3,91 & 3,91 & 2,37 & 2,37 & 3,27 & 3,27 & 2,03 & 2,03 & 3,93 & 3,93 \\
\hline -Bantuan kesehatan & 3,03 & 3,03 & 2,36 & 2,36 & 3,93 & 3,93 & 3,03 & 3,03 & 2,83 & 2,83 & 3,93 & 3,93 \\
\hline -THR & 2,07 & 2,07 & 2,03 & 2,03 & 3,77 & 3,77 & 3,07 & 3,07 & 2,17 & 2,17 & 4,00 & 4,00 \\
\hline -Insentif lain & 2,10 & 2,10 & 2,09 & 2,09 & 3,53 & 3,53 & 2,97 & 2,97 & 2,07 & 2,07 & 3,90 & 3,90 \\
\hline -Keberadaan koperasi & 1,00 & 3,80 & 3,03 & 3,03 & 1,00 & 3,30 & 2,93 & 2,93 & 2,03 & 2,03 & 3,77 & 3,77 \\
\hline -Jamsostek & & 2,87 & & 3,03 & & 2,73 & & 3,10 & & 2,83 & & 3,03 \\
\hline \multicolumn{13}{|l|}{ Aspek Fisik } \\
\hline -Sanitasi & 3,00 & 3,00 & 2,39 & 2,39 & 3,83 & 3,83 & 3,07 & 3,07 & 2,93 & 2,93 & 3,57 & 3,57 \\
\hline -Kesehatan kerja & 3,10 & 3,10 & 2,67 & 2,67 & 3,93 & 3,93 & 3,07 & 3,07 & 2,97 & 2,97 & 3,93 & 3,93 \\
\hline \multicolumn{13}{|l|}{ Aspek Kondisi Kerja } \\
\hline -Perlakuan adil & 3,53 & 3,53 & 2,85 & 2,85 & 4,20 & 4,20 & 3,30 & 3,30 & 3,03 & 3,03 & 4,00 & 4,00 \\
\hline -Waktu kerja & 3,33 & 3,33 & 3,79 & 3,79 & 4,00 & 4,00 & 3,37 & 3,37 & 3,07 & 3,07 & 3,97 & 3,97 \\
\hline -Waktu istirahat & 3,73 & 3,73 & 3,76 & 3,76 & 4,24 & 4,24 & 3,77 & 3,77 & 3,07 & 3,07 & 3,97 & 3,97 \\
\hline -Kesmp. Ibadah & 3,97 & 3,97 & 3,73 & 3,73 & 4,43 & 4,43 & 3,53 & 3,53 & 3,37 & 3,37 & 4,00 & 4,00 \\
\hline -Kesmp. menyusui & 3,07 & 3,07 & 3,00 & 3,00 & 3,30 & 3,30 & 3,10 & 3,10 & 3,03 & 3,03 & 3,00 & 3,00 \\
\hline $\begin{array}{l}\text {-Perlakuan } \\
\text { mandor }\end{array}$ & 3,63 & 3,63 & 3,03 & 3,03 & 4,17 & 4,17 & 3,20 & 3,20 & 2,97 & 2,97 & 3,97 & 3,97 \\
\hline -Tidak ada kekerasan & 3,60 & 3,60 & 3,03 & 3,03 & 3,83 & 3,83 & 3,57 & 3,57 & 3,67 & 3,67 & 3,80 & 3,80 \\
\hline -Kondisi umum & 3,63 & 4,23 & 3,15 & 3,15 & 4,03 & 4,03 & 4,07 & 4,07 & 3,03 & 3,03 & 3,73 & 3,73 \\
\hline \multicolumn{13}{|l|}{ Sosial } \\
\hline -Status pekerjaan & 4,33 & 4,33 & 4,79 & 4,79 & 4,33 & 4,33 & 4,60 & 4,60 & 4,47 & 4,47 & 4,67 & 4,67 \\
\hline $\begin{array}{l}\text {-Kepuasan terhadap } \\
\text { keberadaan SPSI }\end{array}$ & 2,03 & 2,53 & 3,42 & 3,42 & 3,00 & 3,00 & 2,93 & 2,93 & 2,07 & 2,07 & 2,03 & 2,03 \\
\hline -Hub. buruh-perusahaan & 3,77 & 3,77 & 3,21 & 3,21 & 4,47 & 4,47 & 3,67 & 3,67 & 3,63 & 3,63 & 3,77 & 3,77 \\
\hline Rata-rata & 3,16 & 3,22 & 3,19 & 3,25 & 3,60 & 3,66 & 3,47 & $\mathbf{3 , 3 3}$ & 2,87 & 3,02 & $\mathbf{3 , 7 8}$ & 3,81 \\
\hline Kategori & Sdng & Sdng & Sdng & Sdng & Tngi & Tngi & Sdng & Sdng & Sdng & Sdng & Tngi & Tngi \\
\hline
\end{tabular}

Keterangan:

Kategori sangat tinggi: skor $\geq 4,5$; Kategori tinggi: skor 3,5-4,4; Kategori sedang: skor 2,5-3,4; Kategori rendah: skor 1,5-2,4; Kategori sangat rendah: skor $<1,5$ 
Evaluasi Hasil Simulasi Penerapan Model Alternatif

Hasil uji coba penerapan model menunjukkan bahwa perbaikan atribut perlindungan yang dapat dilaksanakan oleh perusahaan adalah atribut yang tidak langsung dapat memenuhi kebutuhan fisik, sehingga hanya mampu meningkatkan skor namun belum dapat meningkatkan kategorinya (Tabel 3). Satu-satunya perbaikan yang menyangkut kebutuhan fisik adalah peningkatan upah sebesar Rp 1000/hari atau Rp 25.000/bulan. Upah setelah kenaikan ternyata masih dibawah UMK, sehingga skornya tetap dua. Hal ini mengisyaratkan bahwa upaya perlindungan terhadap buruh wanita masih perlu untuk terus diupayakan.

Hasil evaluasi penerapan model menunjukkan bahwa kepuasan kerja buruh juga meningkat rata-rata skornya, namun belum mampu meningkatkan kategorinya (Tabel 4). Kebanyakan atribut mempunyai kepuasan kategori sedang, khususnya yang termasuk dalam aspek fisik dan kondisi kerja. Satu-satunya atribut yang mempunyai skor kepuasan sangat tinggi pada semua gudang adalah atribut status pekerjaan. Bekerja pada gudang tembakau memberikan ke- puasan sangat tinggi karena lebih bergengsi dibanding bekerja sebagai buruh tani.

Persepsi buruh terhadap tingkat perlindungan perusahaan yang diwujudkan dalam bentuk kepuasan kerja menunjukkan keharmonisan hubungan industrial. Berdasarkan pada hal tersebut, maka hanya satu gudang yang mempunyai hubungan industrial harmonis, yaitu PTPN X, baik sebelum maupun setelah penerapan simulasi model. Lima gudang lainnya mempunyai hubungan industrial yang belum harmonis (Tabel 5).

\section{Revisi dan Penyempurnaan Model}

Berdasarkan pada hasil simulasi dan evaluasi penerapan model, maka dilakukan revisi dan penyempurnaan model (Gambar 3).

\section{Pemerintah}

Pemerintah menjalankan peran dan fungsi yang sama dengan model tahun ke-1, yaitu:

(a) melakukan pengawasan terhadap pelaksanaan Undang-Undang Ketenagakerjaan.

(b) menjadi fasilitator untuk menciptakan hubungan baik antara perusahaan dan buruh.

Tabel 5. Perbandingan Hubungan Industrial Sebelum dan Sesudah Penerapan Model

\begin{tabular}{|c|c|c|c|c|}
\hline \multirow{2}{*}{ Uraian } & \multicolumn{2}{|c|}{ Skor rata-rata } & \multicolumn{2}{|c|}{ Kategori } \\
\hline & Sebelum & Sesudah & Sebelum & Sesudah \\
\hline \multicolumn{5}{|c|}{ Gudang Pandusata Utama } \\
\hline Perlindungan & 2,81 & 3,17 & Sedang & Sedang \\
\hline Kepuasan & 3,16 & 3,22 & Sedang & Sedang \\
\hline Hubungan industrial & & & Belum harrmonis & Belum harrmonis \\
\hline \multicolumn{5}{|l|}{ Gudang Gading Mas } \\
\hline Perlindungan & 2,96 & 3,35 & Sedang & Sedang \\
\hline Kepuasan & 3,19 & 3,25 & Sedang & Sedang \\
\hline Hubungan industrial & & & Belum harrmonis & Belum harrmonis \\
\hline \multicolumn{5}{|l|}{ Gudang Tempurejo } \\
\hline Perlindungan & 2,76 & 3,13 & Sedang & Sedang \\
\hline Kepuasan & 3,60 & 3,66 & Tinggi & Tinggi \\
\hline Hubungan industrial & & & Belum harrmonis & Belum harmonis \\
\hline \multicolumn{5}{|l|}{ Gudang Tarutama } \\
\hline Perlindungan & 2,76 & 3,26 & Sedang & Sedang \\
\hline Kepuasan & 3,29 & 3,33 & Sedang & Sedang \\
\hline Hubungan industrial & & & Belum harrmonis & Belum harmonis \\
\hline \multicolumn{5}{|c|}{ Gudang Mangli Djaja Raya } \\
\hline Perlindungan & 2,57 & 3,00 & Sedang & Sedang \\
\hline Kepuasan & 2,87 & 3,02 & Sedang & Sedang \\
\hline Hubungan industrial & & & Belum harrmonis & Belum harrmonis \\
\hline \multicolumn{5}{|l|}{ Gudang PTPN X } \\
\hline Perlindungan & 3,57 & 3,91 & Tinggi & Tinggi \\
\hline Kepuasan & 3,78 & 3,81 & Tinggi & Tinggi \\
\hline Hubungan industrial & & & Harmonis & Harmonis \\
\hline
\end{tabular}




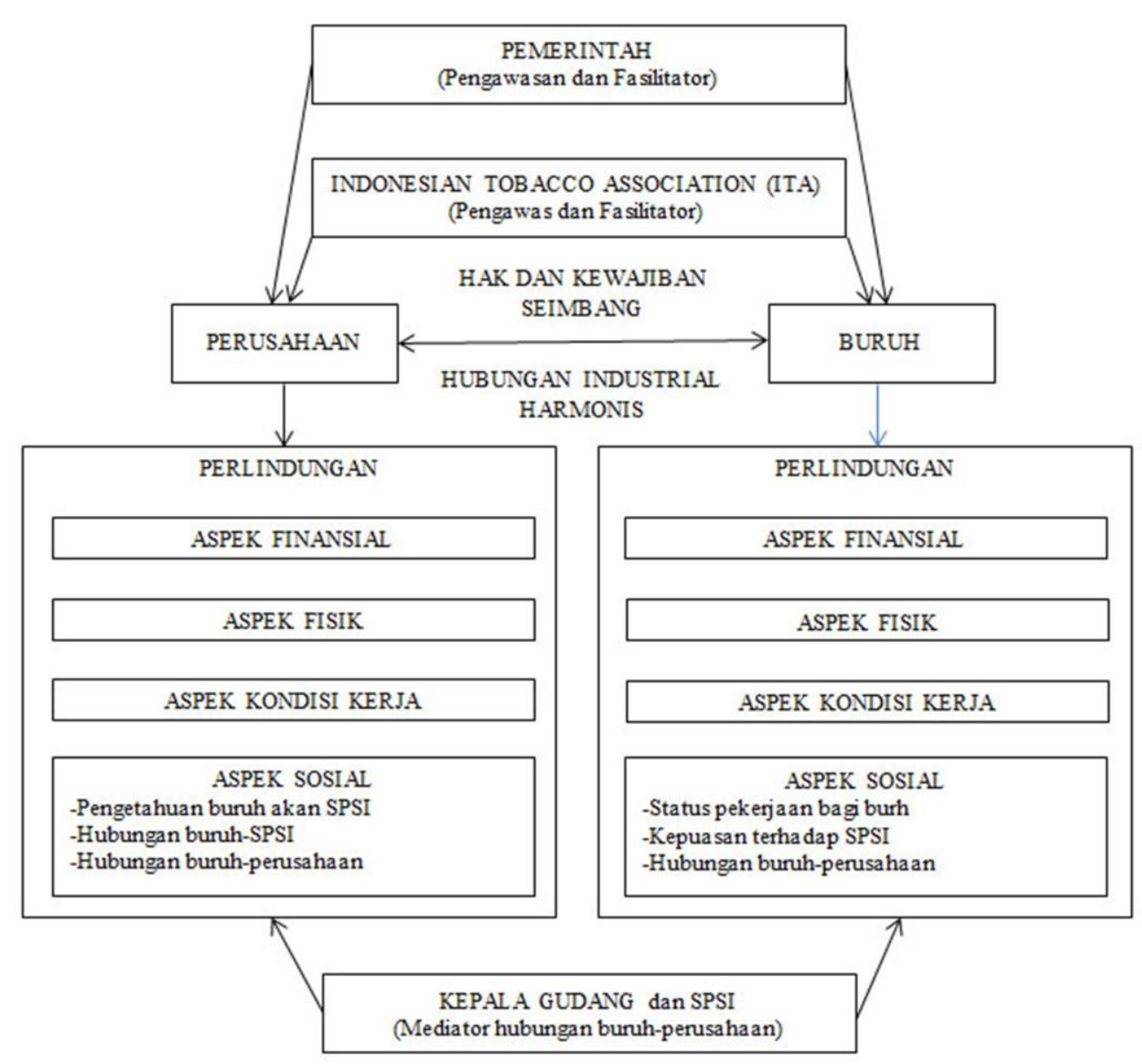

Gambar 3. Model Harmonisasi Hubungan Industrial pada Gudang Tembakau di Kabupaten Jember (Hasil Penyempurnaan Model Tahun ke-1)

\section{Asosiasi Tembakau Indonesia (ATI)}

ATI adalah sebuah lembaga yang dibentuk untuk kemajuan industri tembakau. Peran ATI dipandang sejalan dan mendukung upaya harmonisasi hubungan industrial, sehingga perlu dimasukkan dalam model. Peran ATI antara lain:

(a) membantu pengembangan industri tembakau dan pengawasan pelaksanaan Undang-Undang Ketenagakerjaan.

(b) membantu SPSI memperjuangkan kesejahteraan buruh.

\section{Perusahaan}

Perusahaan mempunyai hak menuntut hasil pekerjaan yang baik dari buruh dan berkewajiban memberikan perlindungan pada buruh yang meliputi aspek finansial, fisik, kondisi kerja, dan sosial. Dari keempat aspek perlindungan, aspek sosial mempunyai peran strategis, karena pada aspek tersebut terdapat SPSI.
SPSI adalah lembaga yang menurut UndangUndang Ketenagakerjaan harus dibentuk oleh perusahaan yang mempekerjakan lebih dari 15 orang buruh. Keberadaan SPSI dimaksudkan sebagai wadah buruh dalam memperjuangkan hak-haknya selama menjalin kemitraan dengan perusahaan sesuai dengan kemampuan perusahaan, sehingga terjalin hubungan baik antara buruh, SPSI dan perusahaan.

\section{Buruh}

Kewajiban buruh adalah bekerja sesuai dengan tuntutan perusahaan. Sebagai imbalan mereka mempunyai hak memperoleh perlindungan perusahaan. Setiap orang yang beraktivitas tentu mengharapkan hasil dari aktivitasnya, begitu juga buruh yang bekerja pada gudang tembakau. Apabila hasilnya dapat memenuhi kebutuhan, maka buruh akan merasakan kepuasan kerja. Semakin banyak kebutuhan yang dapat dipenuhi, maka semakin tinggi tingkat kepuasan kerja. Berdasar teori Maslow yang menyatakan bahwa kebutuhan manusia bukan hanya kebutuhan 
fisik saja, yang dapat dipenuhi dengan adanya aspek finansial, maka kepuasan buruh juga dinilai dari aspek lain selain finansial.

\section{Kepala Gudang}

Dari penelitian tahun pertama diketahui bahwa mandor tidak mempunyai waktu dan kemampuan yang cukup untuk menjadi mediator antara buruh dan perusahaan dalam hal harmonisasi hubungan industrial. Selain melakukan pengawasan dan bimbingan teknis terhadap buruh mandor juga melakukan pekerjaan yang sama dengan buruh selama jam kerja sehingga tidak tersisa cukup waktu untuk melakukan aktivitas lain. Wawasan, kemampuan berorganisasi dan negosiasi mandor relatif kurang karena tingkat pendidikan rata-rata adalah SMP.

Berdasarkan pada hal tersebut, maka peran mandor dalam model harmoniasi hubungan industrial sebagai mediator digantikan oleh kepala gudang, yang mempunyai rata-rata tingkat pendidikan lebih tinggi, dengan peran:

1. Menyampaikan keinginan perusahaan pada buruh untuk mencapai prestasi kerja tertentu.

2. Menyampaikan keinginan buruh pada perusahaan untuk memperoleh haknya.

Beberapa perbedaan antara model lama dengan model yang disempurnakan tercantum pada Tabel 6 . Tugas utama kepala gudang adalah melakukan pengawasan secara umum terhadap proses pengolahan tembakau agar sesuai dengan tuntutan dan target perusahaan. Kondisi kerja gudang tembakau menyebabkan kepala gudang harus memperhatikan kondisi buruh, karena kondisi yang tidak menyenangkan buruh akan berpengaruh pada prestasi kerjanya. Pada bagian inilah peran dan fungsi kepala gudang sebagai mediator diperlukan unuk mempertemukan kepentingan buruh dan perusahaan, agar hak yang diperoleh masing-masing fihak seimbang dengan kewajiban yang dijalankannya.

Peran kepala gudang dalam memperjuangkan kepentingan buruh didukung oleh perusahaan dengan mengizinkannya menjadi pengurus SPSI. Sebagai pengurus, kepala gudang turut menentukan berbagai kebijakan perusahaan terkait kepentingan buruh.

\section{SIMPULAN DAN SARAN}

Model yang dibentuk pada tahun ke-1 masih perlu disempurnakan, berupa: (1) perbaikan atribut perlindungan, yaitu: kenaikan upah rutin, pengadaan lembaga keuangan yang dapat membantu kebutuhan mendadak buruh, asuransi sebagai pengganti JAMSOSTEK, peningkatan pengetahuan buruh akan keberadaan SPSI, perbaikan hubungan buruh dan SPSI serta perbaikan hubungan buruh-perusahaan; (2) dimasukkannya ATI yang mendampingi pemerintah melakukan tugas pengawasan dan fasilitator dalam hubungan industrial pada gudang tembakau; (3) peran mandor sebagai mediator yang menjembatani hubungan buruh dan perusahaan digantikan oleh

Tabel 6. Perbedaan Komponen Model Harmonisasi Hubungan Industrial

\begin{tabular}{|c|c|c|}
\hline Komponen & Semula & Penyempurnaan \\
\hline Pemerintah & $\begin{array}{l}\text { Menjalankan fungsi fasilitator dan pengawasan } \\
\text { terhadap pelaksanaan Undang-undang } \\
\text { ketenagakerjaan }\end{array}$ & $\begin{array}{l}\text { Menjalankan fungsi yang sama sebagaimana pada } \\
\text { model semula }\end{array}$ \\
\hline ITA & Belum dimasukkan dalam model & $\begin{array}{l}\text { Masuk dalam penyempurnaan model dg fungsi: } \\
\text { - } \quad \text { membantu Disnaker mengawasi pelaksanaan } \\
\text { Undang-Undang Ketenagakerjaan pada industri } \\
\text { tembakau } \\
\text { - } \\
\text { membantu perusahaan pengolahan tembakau } \\
\text { dalam pengembangan industri tembakau } \\
\text { - } \\
\text { membantu SPSI memperjuangkan kesejahteraan } \\
\text { buruh }\end{array}$ \\
\hline Mandor & $\begin{array}{l}\text { Merupakan komponen yang menjembatani } \\
\text { hubungan buruh dan perusahaan }\end{array}$ & Tidak lagi dimasukkan dalam penyempurnaan model \\
\hline Kepala Gudang & Tidak dimasukkan dalam model & $\begin{array}{l}\text { Menggantikan fungsi mandor karena lebih kompeten } \\
\text { dan posisinya yang strategis sebagai pengurus SPSI }\end{array}$ \\
\hline Serikat Pekerja & $\begin{array}{l}\text { Dimasukkan dalam model untuk } \\
\text { memperjuangkan hak-hak buruh }\end{array}$ & $\begin{array}{l}\text { Dimasukkan ke dalam model bersamaan dengan } \\
\text { kepala gudang yang berstatus sebagai pengurus SPSI. }\end{array}$ \\
\hline Perusahaan & $\begin{array}{l}\text { Fihak yang mempunyai usaha dan ber- } \\
\text { kewajiban memberikan perlindungan pada } \\
\text { buruh }\end{array}$ & Sama dengan model semula \\
\hline Buruh & $\begin{array}{l}\text { Fihak yang berkewajiban bekerja dan berhak } \\
\text { memperoleh perlindungan yang memberikan } \\
\text { kepuasan kerja }\end{array}$ & Sama dengan model semula \\
\hline
\end{tabular}


kepala gudang, karena lebih kompeten dan strategis karena biasanya merupakan pengurus SPSI.

Hasil simulasi penerapan model hanya mampu meningkatkan skor perlindungan dan kepuasan kerja, namun belum mampu meningkatkan hubungan industrial menjadi harmonis. Empat gudang mempunyai hubungan industrial belum harmonis, karena baik perlindungan maupun kepuasan kerja berada pada kategori sedang. Satu gudang mempunyai hubungan industrial belum harmonis, karena tingkat perlindungan sedang, namun kepuasan kerja tinggi. Hanya gudang PTPN X yang mempunyai hubungan industrial harmonis sebelum dan sesudah penerapan model.

Pemerintah sebaiknya terus bekerjasama dengan ATI dalam melakukan pengawasan pelaksanaan Undang-Undang Ketenagakerjaan pada gudang tembakau dengan tetap mempertimbangkan kemajuan industri tembakau.

Upaya harmonisasi hubungan industrial pada gudang tembakau sebaiknya dimulai dari perbaikan tingkat perlindungan serta optimalisasi peran dan fungsi SPSI. Posisi kepala gudang pada kepengurusan SPSI perlu dipertahankan karena sangat strategis untuk menyampaikan aspirasi dua arah, dari buruh kepada perusahaan dan dari perusahaan kepada buruh, khususnya dalam hal pemenuhan hak-hak buruh.

\section{DAFTAR REFERENSI}

As'ad, M. 2003. Psikologi Industri. Edisi Keempat. Liberty: Yogyakarta.

Azizah, A. 2007. Kekerasan Terhadap Pekerja Perempuan pada Pabrik Tembakau di Kabupaten Jember dan Bondowoso. Laporan Penelitian Kajian Wanita tidak dipublikasikan. Jember: Fakultas Hukum Universitas Jember.

Hadi, S. 1991. Analisis Butir untuk Instrumen Angket, Tes, dan Skala Nilai dengan Basica. Andi Offset: Yogyakarta.

Prayuginingsih, H. 2007. Perlindungan dan Hak Wanita Pekerja Pada Gudang Tembakau (Kasus di Kabupaten Jember). Laporan Penelitian Kajian Wanita tidak dipublikasikan. Jember: Fakultas Pertanian Universitas Muhammadiyah.

Prayuginingsih, H., Santosa, T. H., \& Iman, M. 2010. Model Harmonisasi Hubungan Industrial sebagai Upaya Perlindungan Terhadap Buruh Wanita pada Gudang Tembakau di Kabupaten Jember. Laporan Penelitian Hibah Bersaing Tahun Pertama tidak dipublikasikan. Jember: Fakultas Pertanian Universitas Muhammadiyah Jember.

Simamora, H. 2001. Manajemen Sumber Daya Manusia. Edisi kedua. YPKN: Yogyakarta.

Umar, H. 1998. Riset Sumber Daya Manusia. PT Jakarta: Gramedia Pustaka Utama. 